\title{
Recognizing Indigenous peoples' and local communities' rights and agency in the post-2020 Biodiversity Agenda
}

\author{
Victoria Reyes-García (), Álvaro Fernández-Llamazares, Yildiz Aumeeruddy-Thomas, \\ Petra Benyei, Rainer W. Bussmann, Sara K. Diamond, \\ David García-del-Amo, Sara Guadilla-Sáez, Natalia Hanazaki, \\ Nicolas Kosoy, Margarita Lavides, Ana C. Luz, Pamela McElwee, \\ Vicky J. Meretsky, Teresa Newberry, Zsolt Molnár, \\ Isabel Ruiz-Mallén, Matthieu Salpeteur, Felice S. Wyndham, \\ Francisco Zorondo-Rodriguez, Eduardo S. Brondizio
}

Received: 2 December 2020/Revised: 6 March 2021/Accepted: 26 March 2021/Published online: 18 May 2021

\begin{abstract}
The Convention on Biological Diversity is defining the goals that will frame future global biodiversity policy in a context of rapid biodiversity decline and under pressure to make transformative change. Drawing on the work of Indigenous and non-Indigenous scholars, we argue that transformative change requires the foregrounding of Indigenous peoples' and local communities' rights and agency in biodiversity policy. We support this argument with four key points. First, Indigenous peoples and local communities hold knowledge essential for setting realistic and effective biodiversity targets that simultaneously improve local livelihoods. Second, Indigenous peoples' conceptualizations of nature sustain and manifest CBD's 2050 vision of "Living in harmony with nature." Third, Indigenous peoples' and local communities' participation in biodiversity policy contributes to the recognition of human and Indigenous peoples' rights. And fourth, engagement in biodiversity policy is essential for Indigenous peoples and local communities to be able to exercise their recognized rights to territories and resources.
\end{abstract}

Keywords Biodiversity policy .

Convention on Biological Diversity .

Indigenous and local knowledge · Nature's values .

Right-based approach

\section{INTRODUCTION}

The Convention on Biological Diversity (CBD) is now working to formulate the goals that will frame global biodiversity policy for decades to come. The Parties to the Convention are doing so while facing the fact that they failed to achieve most of the targets of the 2011-2020 Strategic Plan for Biodiversity while global biodiversity continues to decline precipitously (Green et al. 2019). Moreover, the window of opportunity to take action is narrowing (Díaz et al. 2019; IPBES 2019a, b). To slow biodiversity loss, transformative change, i.e., a fundamental system-wide reorganization, is needed in the ways biodiversity policies are designed, implemented, and enforced, from international to national scales, and across sectors (Díaz et al. 2020).

In this 'Perspective', we argue that transformative change requires the foregrounding of Indigenous peoples and local communities' (IPLC) rights and agency in biodiversity policy. Much of the world's biodiversity now exists in landscapes and seascapes traditionally owned, managed, used and/or occupied by IPLC (Brondizio and Le Tourneau 2016; Garnett et al. 2018). Moreover, despite increasing resource extraction pressures (Díaz et al. 2019) and growing violence against IPLC who are defending their territories and resources (Scheidel et al. 2020), biodiversity is declining more slowly in areas managed by IPLC than elsewhere (Garnett et al. 2018; Fa et al. 2020; O'Bryan et al. 2020).

However, IPLC continue to face challenges to full participation in the crafting and implementation of biodiversity policy at local, regional, and global levels (Witter et al. 2015; Forest Peoples Programme et al. 2020). For example, while about $40 \%$ of terrestrial protected areas overlap with IPLC lands (Garnett et al. 2018), IPLC only formally govern $<1 \%$ of them (UNEPWMCM et al. 2018). Further, the current zero draft of the post-2020 biodiversity framework continues to make the same long-standing calls for promotion of traditional knowledge and "full and effective participation" of IPLCs without the more concrete measures they have requested (see Box). 


\section{BOX: IPLC CONTRIBUTIONS TO THE POST-2020 FRAMEWORK}

Preliminary discussions for the post-2020 global biodiversity framework clearly indicated that it "should effectively incorporate gender considerations and the perspectives of Indigenous peoples and local communities" (CBD 2019). Consultations were held with IPLCs to develop the framework in two Global Thematic Dialogue for Indigenous Peoples and Local Communities in 2019-2020, as well as through 17 preparatory webinars across seven regions organized by the International Indigenous Forum on Biodiversity (IIFB) to gather inputs. Other Indigenous-led organizations like the Asia Indigenous Peoples Pact and the Consejo Indígena de Mesoamérica, as well as groups that work closely with IPLCs, like the Indigenous and Community Conserved Areas (ICCA) Consortium, also submitted formal written recommendations to the process. These organizations emphasized the need for the framework to explicitly recognize territorial rights for IPLCs, to request protection for threatened land defenders, and to address mutual sustainability of humans and biodiversity (ICCA 2018; IIFB 2019). For example, one key demand was that target 1 "must include the legal recognition and protection for the territories, land and water of Indigenous peoples and local communities" (CBD 2021). Yet these recommendations are not reflected in the current text of the zero draft (as of early 2021), with only Target 20 addressing IPLCs: "By 2030, ensure equitable participation in decision-making related to biodiversity and ensure rights over relevant resources of Indigenous peoples and local communities, women and girls as well as youth, in accordance with national circumstances." This weaker approach prompted Indigenous participants in the second Global Thematic Dialogue to write to CBD that "the contributions, values, perspectives, knowledge and text proposals of Indigenous peoples and local communities were not adequately taken into account in the updated zero draft of the global biodiversity framework" (CBD 2021).

Four key points underscore the importance of recognizing IPLC rights and agency in biodiversity policy. First, IPLC hold knowledge essential to setting realistic and effective biodiversity targets that simultaneously improve local livelihoods. Second, IPLC conceptualizations and understandings of nature are aligned with CBD's 2050 vision. Third, IPLC participation in biodiversity policy as rights-holders enhances the social elements needed to meet CBD 2050 vision. And fourth, engagement in biodiversity policy is essential for Indigenous peoples and local communities to be able to fully exercise the rights to territories and resources that have been recognized by international agreements. We draw on the work of both Indigenous and non-Indigenous scholars to illustrate these four key points. We acknowledge that we are non-Indigenous academics working in partnership with and informed by IPLC and their representatives. We do not claim to speak on behalf of IPLC, but we gratefully acknowledge the depth of knowledge and perspectives shared with us over the years that shape this 'Perspective'.

\section{IPLC HOLD KNOWLEDGE ESSENTIAL TO SETTING REALISTIC AND EFFECTIVE BIODIVERSITY TARGETS THAT SIMULTANEOUSLY IMPROVE LOCAL LIVELIHOODS}

Scholars and practitioners acknowledge the importance of IPLC's knowledge in advancing scientific understanding of nature (e.g., Athayde et al. 2017; Joa et al. 2018; see also Gadgil et al. 1993; Berkes et al. 2000; Gadgil et al. 2021 for seminal papers on the topic). Indigenous and local knowledge (ILK) has advanced scientific understandings of species' ranges, baselines, and trends and contributed to mapping, monitoring, and reporting changes in local biodiversity, including collective evidence of resource overexploitation, invasive species expansion, pollution, and climate-change impacts (e.g., IPBES 2019a, b; Forest Peoples Programme et al. 2020). As ILK contributions are more valuable when knowledge is embedded into sociocultural contexts, there have been a number of initiatives led by Indigenous peoples and local community organizations to enact a range of monitoring activities on the health of biodiversity, climate-change impacts, effects of unsustainable activities, or implementation of international agreements such as the CBD (Farhan Ferrari et al. 2015; Tengö et al. 2017). For example, the Local Biodiversity Outlook 2, a report compiled in partnership with IPLCs and issued to complement the Global Biodiversity Outlook 5, provides many examples of such on-the-ground initiatives and their contributions to the implementation of the Strategic Plan for Biodiversity 2011-2020 (see Forest Peoples Programme et al. 2020). Nevertheless, current efforts to design and implement a post-2020 global biodiversity framework do not fully acknowledge the importance of ILK for better stewardship of our planet (see Box). For example, while at least $36 \%$ of intact forest landscapes are within Indigenous people's lands (Fa et al. 2020), efforts to preserve these landscapes generally do not 
recognize the multiple values of ILK in their management (Zanotti and Knowles 2020).

Moreover, the holistic nature of ILK is also essential in CBD's quest to set interdependent and mutually reinforcing targets and to minimize trade-offs among targets, including targets set by other international agreements including the Sustainable Development Goals or the United Nations Declaration on the Rights of Indigenous Peoples. For example, protected area expansion can trade-off against IPLC's livelihood options, quality of life, and rights (e.g., Agrawal and Redford 2009; Sayer et al. 2021). Ignoring IPLC and their knowledge in decisions regarding protected area establishment and management would likely be disruptive for local communities and result in conservation failures (Whyte 2018), reinforcing sentiments that conservation can be a colonial enterprise (Whyte 2017). Alternatively, the co-production of new knowledge based on evidence from both science and ILK could contribute to setting realistic and effective biodiversity targets that simultaneously improve local livelihoods (Tengö et al. 2014). Examples exist in which partnership between researchers and IPLC have resulted in emergent knowledge that supports conservation, including for culturally important species and ecosystems (Sterling et al. 2017), and social aspects, such as local governance (Beveridge et al. 2020).

Lack of IPLC agency in biodiversity policy runs the risk of using ILK only for utilitarian ends, particularly if ILK is decontextualized, co-opted and/or instrumentalized for conservationists' purposes, rather than understood as a relational expression based on human-to-nature appreciation and responsibilities (Whyte 2013; Todd 2016). Recognizing IPLC rights and agency in biodiversity management and policy can help prevent conflicts that might arise from extractive uses of ILK (Bohensky and Maru 2011). Transformative change requires that biodiversity policy recognize different worldviews and local forms of relationship to nature, including the emphasis that ILK systems place on nurturing responsible relationships among humans and non-humans (McGregor et al. 2018). Such change also requires that biodiversity policy safeguards IPLC knowledge sovereignty (Kukutai and Taylor 2016), provides IPLC with better access to scientific traditions as a resource for their own purposes, and ultimately accommodates diverse knowledge systems (Díaz-Reviriego et al. 2019).

\section{IPLC UNDERSTANDINGS OF NATURE ARE ALIGNED WITH THE CBD'S 2050 VISION OF "LIVING IN HARMONY WITH NATURE"}

Worldviews that separate humans from the ecosystems they rely on are recognized as an indirect cause of biodiversity decline (Díaz et al. 2019; Forest Peoples Programme et al. 2020). In contrast, IPLC often understand nature as an interconnected web of life, linking humans and non-humans in complex relations (e.g., Lyver et al. 2017; Reo 2019). In such conceptualizations, humans are viewed as an integral component of nature (Coscieme et al. 2020) and nature is imbued with social, cultural and spiritual values (Berkes 2017). Moreover, IPLC conceptualizations of nature often draw on stewardship ethics based on mutual reciprocity between humans and nature, temporary custody for future generations, and health of and attachment to land (Pascua et al. 2017; Reo 2019). These conceptualizations are also dynamic and adapt to external environmental changes (McMillen et al. 2017). They form the basis for land and seascape management, including the protection of sacred areas or species, taboo enforcement, or selective cutting and burning (e.g., Joa et al. 2018). For example, sacred forests -where no extractive activities occur- are common in IPLC lands and allow for the maintenance of forest cover and structure (Samakov and Berkes 2017). Many IPLC also limit the exploitation of resources for certain periods of time or seasons to ensure the maintenance and natural recovery of ecosystems, including forest areas, natural pastures or river sections (e.g., Hammi et al. 2010). Many examples show that management by customary institutions results in more sustainable and productive systems, in ecosystem restoration, or in combatting pollution (e.g., Hoover et al. 2012; Ens et al. 2016; ReyesGarcía et al. 2019; Fernández-Llamazares et al. 2020).

The acknowledgement and inclusion of IPLC's understandings of nature in biodiversity policy design and implementation can be vital to set goals to achieve the CBD's 2050 vision (Sterling et al. 2017). For example, IPLC's conceptualizations of nature can extend ethical concerns to diverse species and natural elements by giving more importance to relational values of nature (e.g., Pascua et al. 2017; Reo 2019). Indeed, examples exist in which IPLC values recognizing the rights of ecosystems to exist, reproduce, and thrive have been enshrined in policy instruments, such as the Ecuadorian Constitution and the Bolivian law in which Mother Earth is granted rights and New Zealand's recognition of the legal personhood of the Whanganui River (Chapron et al. 2019).

Failure to recognize IPLC's rights and agency in designing and implementing biodiversity policy disregards the existence of these different ways to relate with nature. For some authors, this transforms environmental management into a transactional enterprise in which nature is considered a "resource", and the imposition of a single conservation model leads to the erosion of alternative worldviews (e.g., Nadasdy 2003; Eichler and Baumeister 2018). Transformative change requires heeding IPLC voices in global discussions on the collective future of 
humanity and the planet (McGregor et al. 2020) and extending current biodiversity policy frameworks to accommodate IPLC understandings of nature (Tengö et al. 2014; Lyver et al. 2016).

\section{IPLC PARTICIPATION IN BIODIVERSITY POLICY AS RIGHTS-HOLDERS ENHANCES THE SOCIAL BASES NEEDED TO MEET CBD'S 2050 VISION}

IPLC are politically active in the defense of biodiversity, ranging from participating in different scales of governance to resisting environmentally degrading activities. At the local level, lands managed by IPLC have better nature conservation outcomes than other areas (e.g., Garnett et al. 2018; Tran et al. 2020). Moreover, many IPLC participate in monitoring systems to inform implementation and development of conservation indicators and actions (Ens et al. 2016). At the global level, IPLC are increasingly active and insisting on participating in environmental negotiations and intergovernmental processes, such as the involvement of the International Indigenous Peoples' Forum on Climate Change in the 2015 Paris climate conference, where they succeeded in drawing attention to their presence and claims for rights through creative spaces and events (Suiseeya and Zanotti 2019). In other examples, the Inuit Circumpolar Council has been very active in international policy development to reduce pollution burdens, helping shape the Stockholm Convention on Persistent Organic Pollutants, or the Minamata Convention on Mercury (see Fernández-Llamazares et al. 2020). Similarly, Indigenous peoples' organizations such as the Coordinator of Indigenous Organizations of the Amazon River Basin (COICA, for its Spanish acronym) or Tebtebba (Indigenous Peoples' International Center for Policy Research and Education) have played crucial roles in the recognition of Indigenous peoples' rights in the context of UN REDD + negotiations (e.g., Walbott 2014). Using methods that range from direct action to legal claims against transnational corporations, IPLC have also been active political actors against activities potentially leading to environmental degradation including mining operations, hydrocarbon exploration, infrastructure development, and toxic waste dumping (e.g., Spice 2018; Kuokkanen 2019).

A lack of recognition of IPLC rights and their equal participation as stakeholders and leaders in designing biodiversity policy can alienate IPLC by controlling and regulating their resources through processes and institutions that may conflict with their worldviews (Richmond et al. 2013; Tauli-Corpuz et al. 2018). This non-inclusive environmental governance results in IPLC's resistance and noncompliance with top-down environmental regulations that generate conflict over land and resources, forced displacements, and human suffering (Tauli-Corpuz et al. 2018).

Transformative change that includes IPLC's agency in biodiversity policy requires recognizing IPLC stewardship and their effective role in sustaining nature (Armstrong and Brown 2019), promoting IPLC decision-making rights, respecting IPLC laws, principles, and customary practices, and addressing Indigenous peoples' relations with states (Whyte 2017). Transformative change also requires accounting for the negative impacts of agricultural activities, resource extraction, or infrastructural development on nature and for the rights of IPLC (and society in general) to resist such nature damaging activities (IPBES 2019a, b).

\section{ENGAGEMENT IN BIODIVERSITY POLICY IS ESSENTIAL FOR INDIGENOUS PEOPLES TO BE ABLE TO EXERCISE THEIR RECOGNIZED RIGHTS TO TERRITORIES AND RESOURCES}

The Universal Declaration of Human Rights enshrines fundamental human rights to life, liberty, and security, while the United Nations Declaration on the Rights of Indigenous Peoples recognizes their right to self-determination, territories, and resources. Despite these legal recognitions, and compared to other populations, Indigenous peoples often suffer disproportionately from violations of their tenure, access, and resource rights (Giunta 2019; Forest Peoples Programme et al. 2020). For example, resources that support IPLC livelihoods and spiritual and cultural needs are threatened by extractive industries, intensive agriculture, unsustainable fishing, environmental pollution and spread of invasive species (e.g., Hoover et al. 2012; FAO 2016; Kuokkanen 2019). These activities often result in loss of livelihoods, multiple insecurities, land conflicts, and even violence in the name of vested economic or government interests (Martinez-Alier et al. 2016; Scheidel et al. 2020).

When IPLC are not included as equal stakeholders and leaders in biodiversity policy design and implementation, at national and international levels, their power to exercise and defend their recognized rights, including land tenure, resource and access rights, is diminished. For example, setting a target of protecting $30 \%$ of the Earth without IPLC's involvement would not only disempower them, but the implementation of the target might result in numerous violations of their rights. Transformative change in how biodiversity policies are designed and implemented requires not only addressing IPLC's territorial concerns (Zurba et al. 2019) and respecting their governance institutions and practices (Artelle et al. 2019), but also including them as rights-holders in the design and implementation of biodiversity policy at multiple levels. 


\section{CONCLUSION}

IPLC contributions to the enhancement and maintenance of biodiversity in land and seascapes are increasingly acknowledged and a growing number of strategies are being mobilized to work with IPLC in conservation policy (e.g., Hill et al. 2020; McElwee et al. 2020). Yet in the zero draft of the post-2020 global biodiversity framework there is little innovation regarding IPLC rights and agency. Transformative change will require recognizing IPLC rights and agency in biodiversity policy, requiring diverse mechanisms that range from fully acknowledging IPLC contributions and the potential social impacts of conservation, to generating equitable and constructive spaces for dialogue, representation in formal decision-making bodies, state acknowledgement of territorial rights, and developing financial mechanisms that allow engagement and leadership in biodiversity policy design and implementation (Forest Peoples Programme et al. 2020).

Nature's decline is the result of direct and indirect drivers of change-including demographic, economic, political, and institutional arrangements-underpinned by societal values (Díaz et al. 2019). We acknowledge that these drivers interact with one another to impact nature and that the point addressed here is only a piece of the complex puzzle leading to nature's decline. However, we defend that to accomplish the CBD's 2050 vision for biodiversity, global biodiversity institutions, supported by member states, should fully embrace and embody the role of IPLC in the transformative change so widely called upon.

Acknowledgements This manuscript reflects the author's perspective, informed by a review of literature conducted for the Global Assessment of the Intergovernmental Science-Policy Platform for Biodiversity and Ecosystem Services (IPBES). However, this work is not a formal product of IPBES. We thank $\mathrm{H}$. Ngo and $\mathrm{M}$. Guèze (IPBES) and N. Crawhall and P. Bates (UNESCO) for facilitating dialogues with representatives of Indigenous peoples and local communities. We also thank all the Indigenous peoples and local communities who over the years have shared their wisdom, struggles, and hopes with us. We also thank AB. Junqueira, I. Díaz-Reviriego, and $\mathrm{S}$. Gallois for comments on previous versions of this manuscript. VRG received funding from the European Research Council under grant agreement No 771056-LICCI-ERC-2017-COG. This work contributes to the "María de Maeztu" Programme for Units of Excellence (CEX2019-000940-M).

Author contributions VRG and EB conceived the research; all authors reviewed literature; VRG wrote the original draft with contributions from AFLL and PM; all authors edited and approved the manuscript.

\section{Competing interests Authors declare no competing interest.}

Open Access This article is licensed under a Creative Commons Attribution 4.0 International License, which permits use, sharing, adaptation, distribution and reproduction in any medium or format, as long as you give appropriate credit to the original author(s) and the source, provide a link to the Creative Commons licence, and indicate if changes were made. The images or other third party material in this article are included in the article's Creative Commons licence, unless indicated otherwise in a credit line to the material. If material is not included in the article's Creative Commons licence and your intended use is not permitted by statutory regulation or exceeds the permitted use, you will need to obtain permission directly from the copyright holder. To view a copy of this licence, visit http://creativecommons. org/licenses/by/4.0/.

\section{REFERENCES}

Agrawal, A., and K. Redford. 2009. Conservation and displacement: An overview. Conservation and Society 7: 1-10. https://doi.org/ 10.4103/0972-4923.54790.

Armstrong, C.G., and C. Brown. 2019. Frontiers are frontlines: Ethnobiological science against ongoing colonialism. Journal of Ethnobiology 39: 14-31. https://doi.org/10.2993/0278-0771-39. 1.14 .

Artelle, K.A., M. Zurba, J. Bhattacharrya, D.E. Chan, K. Brown, J. Housty, and F. Moola. 2019. Supporting resurgent Indigenousled governance: A nascent mechanism for just and effective conservation. Biological Conservation. https://doi.org/10.1016/j. biocon.2019.108284.

Athayde, S., J. Silva-Lugo, M. Schmink, A. Kaiabi, and M. Heckenberger. 2017. Reconnecting art and science for sustainability: Learning from indigenous knowledge through participatory action-research in the Amazon. Ecology and Society 22: 36. https://doi.org/10.5751/ES-09323-220236.

Berkes, F. 2017. Sacred ecology, 4th ed. London: Routledge.

Berkes, F., J. Colding, and C. Folke. 2000. Rediscovery of traditional ecological knowledge as adaptive management. Ecological Applications 10: 1251-1262. https://doi.org/10.1890/10510761(2000)010.

Beveridge, R., M. Moody, G. Murray, C. Darimont, and B. Pauly. 2020. The Nuxalk Sputc (Eulachon) Project: Strengthening Indigenous management authority through community-driven research. Marine Policy 119: 103971. https://doi.org/10.1016/j. marpol.2020.103971.

Bohensky, E., and Y. Maru. 2011. Indigenous knowledge, science, and resilience: What have we learned from a decade of international literature on 'integration'? Ecology and Society 16: 6. https://doi.org/10.5751/ES-04342-160406.

Brondizio, E., and F.-M. Le Tourneau. 2016. Environmental governance for all. Science 352: 1272-1273.

CBD. 2019. Second synthesis of views of parties and observers on the scope and content of the post-2020 Global Biodiversity Framework. Montreal: Convention on Biological Diversity. https:// www.cbd.int/doc/c/58f8/6926/dc3d8d9f16c9307e91e650e5/ post2020-prep-01-inf-02-en.pdf.

CBD. 2021. Report of the second global thematic dialogue for indigenous peoples and local communities on the post-2020 Global Biodiversity Framework. Montreal: Convention on Biological Diversity. https://www.cbd.int/doc/c/a100/ee24/ d5aff33695045802975e0fa5/post2020-ws-2020-05-02-en.pdf. Accessed 1-3 Dec 2020.

Chapron, G., Y. Epstein, and J.V. López-Bao. 2019. A rights revolution for nature. Science 363: 1392-1393.

Coscieme, L., H. da Silva Hyldmo, Á. Fernández-Llamazares, I. Palomo, T.H. Mwampamba, O. Selomane, N. Sitas, P. Jaureguiberry, et al. 2020. Multiple conceptualizations of nature are key to inclusivity and legitimacy in global environmental governance. Environmental Science \& Policy 104: 36-42. https://doi.org/10.1016/j.envsci.2019.10.018. 
Díaz, S., J. Settele, E.S. Brondízio, H.T. Ngo, J. Agard, A. Arneth, P. Balvanera, K.A. Brauman, et al. 2019. Pervasive human-driven decline of life on Earth points to the need for transformative change. Science 366: eaax3100. https://doi.org/10.1126/science. aax3100.

Díaz, S., N. Zafra-Calvo, A. Purvis, P.H. Verburg, D. Obura, P. Leadley, R. Chaplin-Kramer, L. De Meester, et al. 2020. Set ambitious goals for biodiversity and sustainability. Science. https://doi.org/10.1126/science.abe1530.

Díaz-Reviriego, I., E. Turnhout, and S. Beck. 2019. Participation and inclusiveness in the Intergovernmental Science-Policy Platform on Biodiversity and Ecosystem Services. Nature Sustainability 2: 457-464. https://doi.org/10.1038/s41893-019-0290-6.

Eichler, L., and D. Baumeister. 2018. Hunting for justice: An indigenous critique of the North American Model of Wildlife Conservation. Environment and Society: Advances in Research 9: 75-90. https://doi.org/10.3167/ares.2018.090106.

Ens, E., M.L. Scott, Y.M. Rangers, C. Moritz, and R. Pirzl. 2016. Putting indigenous conservation policy into practice delivers biodiversity and cultural benefits. Biodiversity and Conservation 25: 2889-2906. https://doi.org/10.1007/s10531-016-1207-6.

Fa, J.E., J.E. Watson, I. Leiper, P. Potapov, T.D. Evans, N.D. Burgess, Z. Molnár, Á. Fernández-Llamazares, et al. 2020. Importance of indigenous peoples' lands for the conservation of Intact Forest Landscapes. Frontiers in Ecology and the Environment 18: 135-140. https://doi.org/10.1002/fee.2148.

FAO. 2016. Technical and socio-economic characteristics of smallscale coastal fishing communities, and opportunities for poverty alleviation and empowerment. Rome: FAO.

Farhan Ferrari, M., C. de Jong, and V.S. Belohrad. 2015. Communitybased monitoring and information systems (CBMIS) in the context of the convention on biological diversity (CBD). Biodiversity 16: 57-67. https://doi.org/10.1080/14888386.2015. 1074111.

Fernández-Llamazares, Á., M. Garteizgogeascoa, N. Basu, E.S. Brondizio, M. Cabeza, J. Martínez-Alier, P. McElwee, and V. Reyes-García. 2020. A state-of-the-art review of indigenous peoples and environmental pollution. Integrated Environmental Assessment and Management 16: 324-341. https://doi.org/10. 1002/ieam.4239.

Forest Peoples Programme, International Indigenous Forum on Biodiversity, Indigenous Women's Biodiversity Network Centres of Distinction on Indigenous and Local Knowledge, and Secretariat of the Convention on Biological Diversity. 2020. Local Biodiversity Outlooks 2: The contributions of indigenous peoples and local communities to the implementation of the Strategic Plan for Biodiversity 2011-2020 and to renewing nature and cultures. A complement to the fifth edition of Global Biodiversi. Moreton-in-Marsh: Forest Peoples Programme.

Gadgil, M., F. Berkes, and C. Folke. 1993. Indigenous knowledge for biodiversity conservation. Ambio 22: 151-156.

Gadgil, M., F. Berkes, and C. Folke. 2021. Indigenous knowledge: From local to global. Ambio 50: 967-969. https://doi.org/10. 1007/s13280-020-01478-7.

Garnett, S.T., N.D. Burgess, J.E. Fa, Á. Fernández-Llamazares, Z. Molnár, C.J. Robinson, J.E.M. Watson, K.K. Zander, B. Austin, et al. 2018. A spatial overview of the global importance of Indigenous lands for conservation. Nature Sustainability 1: 369-374. https://doi.org/10.1038/s41893-018-0100-6.

Giunta, A. 2019. Looking back to move forward: The status of environmental rights under the UN Declaration on the Rights of Indigenous Peoples. International Journal of Human Rights 23: 149-173. https://doi.org/10.1080/13642987.2019.1572874.

Green, E.J., G.M. Buchanan, S.H.M. Butchart, G.M. Chandler, N.D. Burgess, S.L.L. Hill, and R.D. Gregory. 2019. Relating characteristics of global biodiversity targets to reported progress. Conservation Biology. https://doi.org/10.1111/cobi.13322.

Hammi, S., V. Simonneaux, J.B. Cordier, D. Genin, M. Alifriqui, N. Montes, and L. Auclair. 2010. Can traditional forest management buffer forest depletion? Dynamics of Moroccan high atlas mountain forests using remote sensing and vegetation analysis. Forest Ecology and Management 260: 1861-1872. https://doi. org/10.1016/j.foreco.2010.08.033.

Hill, R., Ç. Adem, W.V. Alangui, Z. Molnár, Y. AumeeruddyThomas, P. Bridgewater, M. Tengö, R. Thaman, et al. 2020. Working with indigenous, local and scientific knowledge in assessments of nature and nature's linkages with people. Current Opinion in Environmental Sustainability 43: 8-20. https://doi. org/10.1016/j.cosust.2019.12.006.

Hoover, E., K. Cook, R. Plain, K. Sanchez, V. Waghiyi, P. Miller, R. Dufault, C. Sislin, et al. 2012. Indigenous peoples of North America: Environmental exposures and reproductive justice. Environmental Health Perspectives 120: 1645-1649. https://doi. org/10.1289/ehp.1205422.

ICCA Consortium. 2018. Submission in response to the notification requesting views on the preparation, scope and content of the post-2020 Global Biodiversity Framework. https://www.cbd.int/ doc/strategic-plan/Post2020/postsbi/icca.pdf.

IIFB. 2019. Submission for the post-2020 Global Biodiversity Framework, to make progress towards the 2050 vision, strategy and targets for resource mobilisation and collective action. International Indigenous Forum on Biodiversity. https://www. cbd.int/doc/strategic-plan/Post2020/postsbi/iifb1.pdf.

IPBES. 2019a. Summary for policymakers of the global assessment report on biodiversity and ecosystem services of the Intergovernmental Science-Policy Platform on Biodiversity and Ecosystem Services. In Intergovernmental science-policy platform on biodiversity and ecosystem services, ed. S. Díaz, J. Settele, E.S. Brondízio, H.T. Ngo, M. Guèze, J. Agard, A. Arneth, P. Balvanera, et al. Bonn: IPBES secretariat.

IPBES. 2019b. In Global assessment report of the Intergovernmental Science-Policy Platform on Biodiversity and Ecosystem Services, ed. E. S. Brondizio, J. Settele, S. Díaz, and H. T. Ngo. UNIPBES.

Joa, B., G. Winkel, and E. Primmer. 2018. The unknown known-A review of local ecological knowledge in relation to forest biodiversity conservation. Land Use Policy 79: 520-530. https:// doi.org/10.1016/J.LANDUSEPOL.2018.09.001.

Kukutai, T., and J. Taylor. 2016. Indigenous data sovereignty. Indigenous data sovereignty. Camberra: ANU Press. https://doi. org/10.22459/caepr38.11.2016.

Kuokkanen, R. 2019. At the intersection of arctic indigenous governance and extractive industries: Survey of three case studies. The Extractive Industries and Society 6: 15-21.

Lyver, P.O., A. Akins, H. Phipps, V. Kahui, D.R. Towns, and H. Moller. 2016. Key biocultural values to guide restoration action and planning in New Zealand. Restoration Ecology 24: 314-323. https://doi.org/10.1111/rec.12318.

Lyver, P.O.B., P. Timoti, A.M. Gormley, C.J. Jones, S.J. Richardson, B.L. Tahi, and S. Greenhalgh. 2017. Key Māori values strengthen the mapping of forest ecosystem services. Ecosystem Services 27: 92-102. https://doi.org/10.1016/j.ecoser.2017.08. 009.

Martinez-Alier, J., L. Temper, D. Del Bene, and A. Scheidel. 2016. Is there a global environmental justice movement? The Journal of Peasant Studies 43: 731-755. https://doi.org/10.1080/03066150. 2016.1141198.

McElwee, P., Á. Fernández-Llamazares, Y. Aumeeruddy-Thomas, D. Babai, P. Bates, K. Galvin, M. Guèze, J. Liu, et al. 2020. Working with Indigenous and Local Knowledge (ILK) in LargeScale Ecological Assessments: Reviewing the experience of the 
IPBES Global Assessment. Applied Ecology. https://doi.org/10. 1111/1365-2664.13705.

McGregor, D., J.-P. Restoule, and R. Johnston. 2018. Indigenous research: Theories, practices, and relationships. Toronto: Canadian Scholars' Press.

McGregor, D., S. Whitaker, and M. Sritharan. 2020. Indigenous environmental justice and sustainability. Current Opinion in Environmental Sustainability 43: 35-40. https://doi.org/10.1016/ j.cosust.2020.01.007.

McMillen, H., T. Ticktin, and H. Kihalani. 2017. The future is behind us: Traditional ecological knowledge and resilience over time on Hawai'i Island. Regional Environmental Change 17: 579-592. https://doi.org/10.1007/s10113-016-1032-1.

Nadasdy, P. 2003. Hunters and bureaucrats: Power, knowledge and aboriginal-state relations in the southwest Yukon, 1st ed. Vancouver: University of British Columbia Press.

O'Bryan, C.J., S.T. Garnett, J.E. Fa, I. Leiper, J. Rehbein, Á. Fernández-Llamazares, M.V. Jackson, H.D. Jonas, et al. 2020. The importance of indigenous peoples' lands for the conservation of terrestrial mammals. Conservation Biology. https://doi. org/10.1111/cobi.13620.

Pascua, P., H. McMillen, T. Ticktin, M. Vaughan, and K.B. Winter. 2017. Beyond services: A process and framework to incorporate cultural, genealogical, place-based, and indigenous relationships in ecosystem service assessments. Ecosystem Services 26: 465-475. https://doi.org/10.1016/j.ecoser.2017.03.012.

Reo, N.J. 2019. Inawendiwin and relational accountability in Anishnaabeg studies: The crux of the biscuit. Journal of Ethnobiology 39: 65. https://doi.org/10.2993/0278-0771-39.1.65.

Reyes-García, V., Á. Fernández-Llamazares, P. McElwee, Z. Molnár, K. Öllerer, S.J. Wilson, and E.S. Brondizio. 2019. The contributions of Indigenous Peoples and local communities to ecological restoration. Restoration Ecology 27: 3-8. https://doi. org/10.1111/rec.12894.

Richmond, L., B.R. Middleton, R. Gilmer, Z. Grossman, T. Janis, S. Lucero, T. Morgan, and A. Watson. 2013. Indigenous studies speaks to environmental management. Environmental Management 52: 1041-1045. https://doi.org/10.1007/s00267-013-0173y.

Samakov, A., and F. Berkes. 2017. Spiritual commons: Sacred sites as core of community-conserved areas in Kyrgyzstan. International Journal of the Commons 11: 422. https://doi.org/10.18352/ijc. 713.

Sayer, J., C. Margules, and J.A. McNeely. 2021. People and biodiversity in the 21st Century. Ambio 50: 970-975. https:// doi.org/10.1007/s13280-020-01476-9.

Scheidel, A., D. Del Bene, J. Liu, G. Navas, S. Mingorría, F. Demaria, S. Avila, B. Roy, et al. 2020. Environmental conflicts and defenders: A global overview. Global Environmental Change. https://doi.org/10.1016/j.gloenvcha.2020.102104.

Spice, A. 2018. Fighting invasive infrastructures: Indigenous relations against pipelines. Environment and Society: Advances in Research 9: 40-56. https://doi.org/10.3167/ares.2018.090104.

Sterling, E.J., C. Filardi, A. Toomey, A. Sigouin, E. Betley, N. Gazit, J. Newell, S. Albert, et al. 2017. Biocultural approaches to wellbeing and sustainability indicators across scales. Nature Ecology \& Evolution 1: 1798-1806. https://doi.org/10.1038/s41559-0170349-6.

Suiseeya, K.R., and L. Zanotti. 2019. Making influence visible: Innovating ethnography at the paris climate summit. Global Environmental Politics 19: 38-60.

Tauli-Corpuz, V., J. Alcorn, and A. Molnar. 2018. Cornered by protected areas: Replacing 'fortress' conservation with rightsbased approaches helps bring justice for indigenous peoples and local communities, reduces conflict, and enables cost-effective conservation and climate action. Washington, DC: Rights and Resources Initiative.

Tengö, M., E.S. Brondizio, T. Elmqvist, P. Malmer, and M. Spierenburg. 2014. Connecting diverse knowledge systems for enhanced ecosystem governance: The multiple evidence base approach. Ambio 43: 579-591. https://doi.org/10.1007/s13280014-0501-3.

Tengö, M., R. Hill, P. Malmer, C.M. Raymond, M. Spierenburg, F. Danielsen, T. Elmqvist, and C. Folke. 2017. Weaving knowledge systems in IPBES, CBD and beyond-Lessons learned for sustainability. Current Opinion in Environmental Sustainability 26-27: 17-25. https://doi.org/10.1016/J.COSUST.2016.12.005.

Todd, Z. 2016. An Indigenous Feminist's take on the ontological turn: "Ontology" is just another word for colonialism. Journal of Historical Sociology 29: 4-22. https://doi.org/10.1111/johs. 12124.

Tran, T.C., N.C. Ban, and J. Bhattacharyya. 2020. A review of successes, challenges, and lessons from Indigenous protected and conserved areas. Biological Conservation. https://doi.org/10. 1016/j.biocon.2019.108271.

UNEP-WCMC, IUCN and NGS. 2018. Protected Planet Report 2018. UNEP-WCMC, IUCN and NGS: Cambridge UK; Gland, Switzerland; and Washington, D.C., USA.

Wallbott, L. 2014. Indigenous peoples in UN REDD + negotiations: "Importing power" and lobbying for rights through discursive interplay management. Ecology and Society 19: 21. https://doi. org/10.5751/ES-06111-190121.

Whyte, K.P. 2013. Justice forward: Tribes, climate adaptation and responsibility. Climatic Change 120: 517-530.

Whyte, K.P. 2017. Our ancestors' dystopia now: Indigenous conservation and the Anthropocene. In The Routledge companion to the environmental humanities, ed. U.K. Heise, J. Christensen, and M. Niemann, 222-231. London: Routledge. https://doi.org/10. 4324/9781315766355-32.

Whyte, K.P. 2018. What do indigenous knowledges do for indigenous peoples? In Traditional ecological knowledge, 57-82. Cambridge: Cambridge University Press. https://doi.org/10.1017/ 9781108552998.005.

Witter, R., K.R. Marion Suiseeya, R.L. Gruby, S. Hitchner, E.M. Maclin, M. Bourque, and J.P. Brosius. 2015. Moments of influence in global environmental governance. Environmental Politics 24: 894-912. https://doi.org/10.1080/09644016.2015. 1060036.

Zanotti, L., and N. Knowles. 2020. Large intact forest landscapes and inclusive conservation: A political ecological perspective. Journal of Political Ecology 27: 539-557. https://doi.org/10.2458/ V27I1.23165.

Zurba, M., K. Beazley, E. English, and J. Buchmann-Duck. 2019. Indigenous Protected and Conserved Areas (IPCAs), Aichi Target 11 and Canada's Pathway to Target 1: Focusing conservation on reconciliation. Land 8: 10. https://doi.org/10. 3390/land8010010.

Publisher's Note Springer Nature remains neutral with regard to jurisdictional claims in published maps and institutional affiliations.

\section{AUTHOR BIOGRAPHIES}

Victoria Reyes-García $(\square)$ is ICREA Research Professor at the Institute of Environmental Science and Technology of the Autonomous University of Barcelona (ICTA-UAB). Her research interest include biocultural diversity, conservation and climate change impacts.

Address: Institució Catalana de Recerca i Estudis Avançats (ICREA), Barcelona, Spain. 
Address: Institut de Ciència i Tecnologia Ambientals (ICTA), Universitat Autònoma de Barcelona (UAB), Carrer de les columnes, $\mathrm{s} / \mathrm{n}$. Z-building (ICTA-ICP), Bellaterra Campus, Cerdanyola del Valles, Bellatera, 08193 Barcelona, Spain.

e-mail: victoria.reyes@uab.cat

Álvaro Fernández-Llamazares is a postdoctoral research fellow at the Helsinki Institute of Sustainability Science (HELSUS) of the University of Helsinki, Finland. His research interests include biocultural approaches to conservation, ethnobiology and Indigenous land governance.

Address: Helsinki Institute of Sustainability Science (HELSUS), Faculty of Biological and Environmental Sciences, University of Helsinki, P.O. Box 65, (Viikinkaari 1), 00014 Helsinki, Finland.

e-mail: alvaro.fernandez-llamazares@helsinki.fi

Yildiz Aumeeruddy-Thomas is Director of Research at the CNRS, Centre for Functional and Evolutionary Ecology, Biocultural Interactions and Adaptation Team, in Montpellier. Her research focused over the last 30 years in tropical, Himalayan and, now, Mediterranean sites and localities on local traditional knowledge about agrobiodiversity, and local social-ecological dynamics of agroecosystems within anthropogenic landscapes.

Address: Centre for Functional and Evolutionary Ecology, University Montpellier, CNRS, CEFE, UMR 5175, 1919, Route de Mende, 34293 Montpellier, France.

e-mail: yildiz.aumeeruddy-thomas@cefe.cnrs.fr

Petra Benyei is a postdoctoral fellow at the Universitat Autònoma de Barcelona. Her research interests include the evaluation of transdisciplinary approaches (including citizen/community science) to document, share, and protect indigenous and local knowledge as a commons.

Address: Institut de Ciència i Tecnologia Ambientals (ICTA), Universitat Autònoma de Barcelona (UAB), Carrer de les columnes, s/n. Z-building (ICTA-ICP), Bellaterra Campus, Cerdanyola del Valles, Bellatera, 08193 Barcelona, Spain.

e-mail: petra.benyei@uab.cat

Rainer W. Bussmann is a Professor at the Department of Ethnobotany, Institute of Botany, Ilia State University, Tbilisi, Georgia. His research focuses on ethnobotanical research, and the preservation of traditional knowledge, in the Andes, the Caucasus, and the Himalayas.

Address: Department of Ethnobotany, Institute of Botany and Bakuriani Alpine Botanical Garden, Ilia State University, Tbilisi, Georgia.

e-mail: rainer.bussmann@iliauni.edu.ge

Sara K. Diamond is a $\mathrm{PhD}$ graduate from the Department of Geography and The Environment at the University of Texas at Austin. Her current research examines drivers of natural resource use and governance strategies in rural communities in the Peruvian Amazon. Address: Department of Geography and the Environment, University of Texas, Austin, USA.

Address: College of Liberal Arts, The University of Texas at Austin, 116 Inner Campus Dr. Stop G6000, Austin, TX 78712, USA.

e-mail: sdiamond@utexas.edu

David García-del-Amo is a doctoral candidate at the Environmental Science and Technology Institute from the Autonomous University of Barcelona (ICTA-UAB). His research interests include rural communities, Indigenous and Local Knowledge, co-production of knowledge, co-management, climate change, sustainability, and cultural and biodiversity conservation.
Address: Institut de Ciència i Tecnologia Ambientals (ICTA), Universitat Autònoma de Barcelona (UAB), Carrer de les columnes, s/n. Z-building (ICTA-ICP), Bellaterra Campus, Cerdanyola del Valles, Bellatera, 08193 Barcelona, Spain.

e-mail: David.garcia.delamo@uab.cat

Sara Guadilla-Sáez is an independent researcher. Her interests include traditional ecological knowledge, biodiversity conservation and community-based natural resources management.

Address: Independent Researcher, Barcelona, Spain.

e-mail: sguadillasaez@gmail.com

Natalia Hanazaki is a full professor at Universidade Federal de Santa Catarina, Brazil. Her research interests include human ecology, ethnobiology and traditional ecological knowledge, and biodiversity conservation. Address: Departamento de Ecologia e Zoologia, Universidade Federal de Santa Catarina, ECZ/CCB/UFSC, Campus Trindade s/n, Florianópolis, SC 88010-970, Brazil.

e-mail: natalia.hanazaki@ufsc.br; hanazaki@gmail.com

Nicolas Kosoy is an Associate Professor at McGill University. His research interest include ecological economics, heterodox valuation, political ecology and political economy.

Address: Faculty of Agricultural and Environmental Sciences, McGill School of Environment, McGill University, Macdonald Stewart Building, MS3-037, Macdonald Campus, Ste. Anne-de-Bellevue, Quebec H9X 3V9, Canada.

e-mail: nicolas.kosoy@mcgill.ca

Margarita Lavides $\mathrm{PhD}$, a Research Fellow at Earth Law Center, New York City and a Biology educator at New York City Department of Education. Her research interests include coral reef fish local extinction, marine protected areas, climate change, socio-ecological system, indigenous and local knowledge.

Address: Earth Law Center, New York, NY, USA.

e-mail: MLavides2@schools.nyc.gov

Ana C. Luz is an Invited Researcher at ISEG - Lisbon School of Economics and Management, Portugal. Her research interests include the study of social-ecological links in urban and rural systems, and biodiversity conservation.

Address: ISEG- Lisbon School of Economics \& Management, Universidade de Lisboa, Lisbon, Portugal.

e-mail: aluz@iseg.ulisboa.pt

Pamela McElwee is Associate Professor of Human Ecology at Rutgers, The State University of New Jersey. Her research interests include ecosystem services, land-based climate mitigation, and vulnerability and adaptation to global environmental change.

Address: Department of Human Ecology, Rutgers University, 55 Dudley Road, New Brunswick, NJ 08901, USA.

e-mail: pamela.mcelwee@ rutgers.edu

Vicky J. Meretsky is a professor, O'Neill School of Public and Environmental Affairs at Indiana University. Her research interests include conservation of imperiled species, collaborative conservation, and conservation planning, particularly under climate change.

Address: O'Neill School of Public and Environmental Affairs, Indiana University, Bloomington, IN 47405, USA.

e-mail: meretsky@indiana.edu

Teresa Newberry is a Professor of Biology and Academic Chair of Science and Health at Tohono O'odham Community College. Her research interests include preservation of biocultural diversity and traditional ecological knowledge, indigenous education, and ecosystem response to climate change. 
Address: Department of Science, Tohono O'odham Community College, Sells, 1830 E. Broadway, Ste 124-202, Tucson, AZ 85719, USA.

e-mail: tnewberry@tocc.edu

Zsolt Molnár is a scientific advisor at the Centre for Ecological Research, Hungary. His research interest includes traditional ecological knowledge, historical landscape ecology and nature conservation management.

Address: Centre for Ecological Research, ELKH, Alkotmány u. 2-4, Vácrátót 2163, Hungary.

e-mail: molnar.zsolt@ecolres.hu

Isabel Ruiz-Mallén is a 'Ramón y Cajal' Senior Research Fellow at the IN3-Universitat Oberta de Catalunya (UOC), Spain. Her research interests lie in knowledge co-production and transformative learning processes behind sustainability and science education, communitybased conservation and grassroots climate resilience.

Address: Internet Interdisciplinary Institute, Universitat Oberta de Catalunya, Av. Friedrich Gauss, 5, Castelldefels, 08860 Barcelona, Spain.

e-mail: iruiz_mallen@uoc.edu

Matthieu Salpeteur is an anthropologist, researcher at the French National Research Institute for Sustainable Development (IRD), member of the PALOC team (MNHN-IRD), Muséum national d'histoire naturelle, Paris. His research interests revolve around contemporary transformations in pastoral systems, local ecological knowledge, agrobiodiversity dynamics.

Address: Patrimoines Locaux, Environnement et Globalisation (UMR 208 PALOC), IRD, MNHN, French National Research Institute for Sustainable Development (IRD), 57 rue Cuvier, CP 51, 75231 Paris Cedex 05, France.

e-mail: matthieu.salpeteur@ird.fr
Felice S. Wyndham is an independent scholar and research affiliate at the School of Anthropology and Museum Ethnography at the University of Oxford. Her ecological anthropology research on narrating landscapes explores the ways we relate to places and other living things by examining the intersections of stories and ecological knowing, of landscapes and memory.

Address: School of Anthropology and Museum Ethnography, University of Oxford, Oxford, UK.

Address: PO Box 3162, Santa Cruz, CA 95063, USA.

e-mail: felice.wyndham@anthro.ox.ac.uk

Francisco Zorondo-Rodriguez is Assistant Professor at Departamento de Gestión Agraria of the Universidad de Santiago de Chile. His research lines focus on the contribution of biodiversity to human well-being, and relationships of local communities with protected areas and other biodiversity management tools.

Address: Departamento de Gestión Agraria, Facultad Tecnológica, Universidad de Santiago de Chile, Santiago, Chile.

e-mail: francisco.zorondo@usach.cl

Eduardo S. Brondizio is Distinguished Professor of Anthropology Indiana University-Bloomington and collaborating professor of the Society and Environment Program at the University of Campinas, Brazil. His research combines long-term understanding of the socialenvironmental transformation of the Amazon and international collaborative research on the human dimensions of global environmental and climate change.

Address: Department of Anthropology, Indiana University Bloomington, 702 E. Kirkwood Ave. Student building 130, Bloomington, IN 47401, USA.

e-mail: ebrondiz@iu.edu 